\title{
Multinucleation and cell dysfunction induced by amorphous silica nanoparticles in an L-02 human hepatic cell line
}

This article was published in the following Dove Press journal:

International Journal of Nanomedicine

18 September 2013

Number of times this article has been viewed

\author{
Wen Wang ${ }^{1-3, *}$ \\ Yang $\mathrm{Li}^{1-3, *}$ \\ Xiaomei Liu ${ }^{3}$ \\ Minghua Jin ${ }^{3}$ \\ Haiying $D^{3}$ \\ Ying Liu $^{3}$ \\ Peili Huang ${ }^{1,2}$ \\ Xianqing Zhou ${ }^{1,2}$ \\ Lan Yuan ${ }^{4}$ \\ Zhiwei Sun ${ }^{1-3}$ \\ 'School of Public Health, Capital \\ Medical University, Beijing, ${ }^{2}$ Beijing \\ Key Laboratory of Environmental \\ Toxicology, Capital Medical University, \\ Beijing, ${ }^{3}$ School of Public Health, Jilin \\ University, Changchun, Jilin, ${ }^{4}$ Medical \\ and Healthy Analysis Centre, Peking \\ University, Beijing, People's Republic \\ of China \\ *These authors contributed equally \\ to this work
}

Correspondence: Zhiwei Sun School of Public Health, Capital Medical University, Beijing 100069 , People's Republic of China

Tel $+86 \quad 108391 \quad 1507$

Fax +86 I0 839। I507

Email zwsun@ccmu.edu.cn

Lan Yuan

Medical and Healthy Analysis Centre, Peking University, Peking University,

38 Xueyuan Road, Beijing 100191,

People's Republic of China

Tel +86 I0 82802389

Fax +86 I0 82802389

Email yuan_lan@bjmu.edu.cn
Abstract: Silica nanoparticles (SNPs) are one of the most important nanomaterials, and have been widely used in a variety of fields. Therefore, their effects on human health and the environment have been addressed in a number of studies. In this work, the effects of amorphous SNPs were investigated with regard to multinucleation in L-02 human hepatic cells. Our results show that L-02 cells had an abnormally high incidence of multinucleation upon exposure to silica, that increased in a dose-dependent manner. Propidium iodide staining showed that multinucleated cells were arrested in G2/M phase of the cell cycle. Increased multinucleation in L-02 cells was associated with increased generation of cellular reactive oxygen species and mitochondrial damage on flow cytometry and confocal microscopy, which might have led to failure of cytokinesis in these cells. Further, SNPs inhibited cell growth and induced apoptosis in exposed cells. Taken together, our findings demonstrate that multinucleation in L-02 human hepatic cells might be a failure to undergo cytokinesis or cell fusion in response to SNPs, and the increase in cellular reactive oxygen species could be responsible for the apoptosis seen in both mononuclear cells and multinucleated cells.

Keywords: silica nanoparticles, human hepatic cell L-02, multinucleation, cell cycle, cell dysfunction, apoptosis

\section{Introduction}

Nanotechnology can be defined as the science and engineering involved in the design, synthesis, characterization, and application of materials and devices, the smallest organization of which in at least one dimension is on the nanometer scale. ${ }^{1}$ The rapid development of nanotechnology in recent years has created a myriad of engineered nanomaterials, including silica nanoparticles (SNPs), which are increasingly being used in industrial processes as well as in scientific, biological, and medical research. ${ }^{2,3}$ The direct impact of these materials on human health and the environment is of great concern to the population. ${ }^{4}$

Recent investigations have indicated that SNPs can enter the body through the respiratory system, digestive tract, skin, and blood circulation, and accumulate in vital internal organs, including the lung, liver, spleen, and kidney, causing inflammation and severe tissue damage. ${ }^{5-7}$ It has been confirmed in previous in vitro studies that SNPs can cross the cell membrane, distribute into the cytoplasm and nucleus, ${ }^{8,9}$ and cause cytotoxicity and genotoxicity in many cell lines. ${ }^{10-12}$

Multinucleation can be divided into syncytium and plasmodium. ${ }^{13} \mathrm{~A}$ syncytium is generated by cell fusion, ${ }^{14}$ and is frequently observed in normal tissue. Multinucleated osteoclasts are formed by fusion of mononuclear cells in the process of bone resorption. ${ }^{15}$ 
Macrophages can fuse to become multinuclear giant cells when adequately stimulated extracellularly. ${ }^{16} \mathrm{~A}$ plasmodium is formed by karyokinesis without cytokinesis, and results in polyploidy or aneuploidy, such as in normal hepatocytes during growth of liver tissue. ${ }^{17,18}$ Plasmodium seems to be due to failure to form the central spindle and contractile ring, resulting from many mechanisms, such as lipid metabolism and abnormalities of the actin filaments and microtubules. ${ }^{19}$ Further, formation of polyploidy and aneuploidy is the early event and main mark for a majority of solid tumors. ${ }^{20}$ Abnormal cell division can decrease genomic stability and increase the risk of tumors. ${ }^{21}$

It has been reported that some types of nanomaterials can enter cells, cause cytoskeletal dysfunction, ${ }^{22,23}$ and result in formation of multinucleated cells. ${ }^{24}$ In general, reactive oxygen species (ROS) generation induced by nanoparticles is considered to be one of the important mechanisms associated with their toxicity. ${ }^{25}$ Research indicates that SNPs increase intracellular ROS levels, and result in cellular dysfunction in several cultured cell lines. ${ }^{26-28}$ Meanwhile, additional ROS could induce amplification of multipolar spindles and irregular centrosomes, ${ }^{29}$ which might lead to formation of multinucleated cells.

In a previous study, we reported for the first time that SNPs could induce multinucleation in HepG2 cells. ${ }^{30}$ Interestingly, a similar result was obtained in L-02 cells in the present study. It was hypothesized that multinucleation in L-02 cells represents a failure to undergo cytokinesis or cell fusion resulting from extracellular ROS induced by SNPs. In this paper, we demonstrate that multinucleation of L-02 human liver cells can be induced in vitro in response to SNPs. Intracellular ROS generation, mitochondrial damage, arrest of the cell cycle, and apoptosis of L-02 cells were also investigated to clarify further the possible mechanisms of multinucleation.

\section{Materials and methods}

\section{Preparation of amorphous SNPs}

Amorphous SNPs were synthesized using the Stöber ${ }^{31}$ method. Tetraethoxysilane (Tiantai Chemical Co Ltd, Wuhan, People's Republic of China) was distilled under reduced pressure before use. Pure grade ethanol (99\%, Beijing Chemical Reagent Company, Beijing, People's Republic of China) and ammonium hydroxide (25\%, Beijing Chemical Reagent Company) were used as received. Water was of high purity grade with a resistivity of $18.2 \mathrm{M} \Omega \mathrm{cm}$. Briefly, the SNPs were prepared by adding $0.3 \mathrm{~mL}$ of tetraethoxysilane to $30 \mathrm{~mL}$ of premixed ethanol solution containing $1.0 \mathrm{~mL}$ of ammonium hydroxide and $0.6 \mathrm{~mL}$ of water. The mixture was kept in a $40^{\circ} \mathrm{C}$ bath and magnetically stirred for 3 hours. Another $0.3 \mathrm{~mL}$ of tetraethoxysilane was then added and reacted for 3 hours. Finally, the SNPs were isolated by centrifugation for 15 minutes at 12,000 rpm and washed twice with ethanol and water, then redispersed in $30 \mathrm{~mL}$ of high purity water. The suspension of SNPs was then sterilized by autoclaving at $121^{\circ} \mathrm{C}$ for 20 minutes before the biological experiments.

\section{Characterization of SNPs}

First, $1 \mathrm{~mL}$ of the suspension was allowed to dry at $80^{\circ} \mathrm{C}$ for 24 hours, the residue was weighed, and the concentration of particles was calculated. The morphology and average size of the SNPs was observed using a transmission electron microscope (JEOL Ltd, Tokyo, Japan). Purity of the SNPs was assessed by inductively coupled plasma atomic emission spectrometry (Thermo Fisher Scientific, ARL 3520, Ecublens, Switzerland). A zeta electric potential granulometer (Malvern Instruments, Malvern, UK) was used to determine the zeta potential and hydrodynamic size of the SNPs in distilled water and Roswell Park Memorial Institute (RPMI) 1640 culture medium (Gibco, Grand Island, NY, USA).

\section{Cell culture and treatment with SNPs}

An L-02 human hepatic cell line obtained from the Cell Resource Center, Shanghai Institutes for Biological Sciences, Chinese Academy of Sciences, was cultured in RPMI 1640 medium supplemented with $10 \%$ fetal bovine serum (HyClone, Logan, UT, USA), $100 \mathrm{U} / \mathrm{mL}$ penicillin, and $100 \mu \mathrm{g} / \mathrm{mL}$ streptomycin, and grown at $37^{\circ} \mathrm{C}$ in a humidified $5 \% \mathrm{CO}_{2}$ environment. Cells used in this study were in early passages (10-30).

For the experiments, the cells were seeded in culture plates at a density of $1 \times 10^{5}$ cells $/ \mathrm{mL}$ and allowed to attach for 24 hours, then treated with SNPs suspended in RPMI 1640 culture medium for another 24 hours. SNP suspensions were formed using a sonicator $(160 \mathrm{~W}, 20 \mathrm{kHz}, 5$ minutes, KQ-250B, Kunshan Ultrasonic Instruments Co Ltd, Jiangsu, People's Republic of China) and diluted to four concentrations $(50,100,150$, and $200 \mu \mathrm{g} / \mathrm{mL})$, then applied immediately to the L- 02 cells. Cells maintained in RPMI 1640 culture medium without SNPs were used as the control. Each group had five replicate wells.

\section{Assessment of cytotoxicity}

The effect of SNPs on cell viability was determined using a cell counting kit (CCK-8, Dojindo Laboratories, 
Kumamoto, Japan), which is more sensitive than the MTT assay. Briefly, L-02 cells were incubated with or without the various concentrations of SNPs for 24 hours. Next, $10 \mu \mathrm{L}$ of CCK-8 solution was added to each well, and the cells were incubated for a further 2 hours at $37^{\circ} \mathrm{C}$. The plate was then read using a Sunrise microplate reader (Tecan Austria $\mathrm{GmbH}$, Grödig, Austria) at $450 \mathrm{~nm}$.

\section{Assessment of multinucleation}

After attachment, the cells were incubated with 50, 100, 150, or $200 \mu \mathrm{g} / \mathrm{mL}$ of SNPs for 24 hours. The medium was then removed, and the cells were washed twice with phosphatebuffered saline and stained with $10 \mu \mathrm{g} / \mathrm{mL}$ Hoechst $33258 \mathrm{solu}-$ tion (Sigma, St Louis, MO, USA) for 45 minutes and $5 \mu \mathrm{g} / \mathrm{mL}$ of fluorescein diacetate (Sigma) for 10 minutes at $37^{\circ} \mathrm{C}$ in the dark. The cells were visualized by ultraviolet excitation and photographed using a laser confocal microscope (model TCSNT, Leica, Heidelberg, Germany). Fields were selected at random, numbers of binucleated and multinucleated cells were counted manually by two independent observers, and the rate of total multinucleated cells was then calculated.

\section{Assessment of cell cycle}

Following treatment with different concentrations of SNPs for 24 hours, the cells were harvested by centrifugation for 5 minutes at $4^{\circ} \mathrm{C}$ and $1,000 \mathrm{rpm}$, then washed twice with ice-cold phosphate buffered saline-ethylenediamine tetraacetic acid (PBS-EDTA), fixed in ice-cold 70\% ethanol, and frozen at $20^{\circ} \mathrm{C}$ overnight. On the following day, the cells were washed twice with PBS-EDTA and resuspended in $450 \mu \mathrm{L}$ of PBS-EDTA solution containing $7.5 \mu \mathrm{M}$ of propidium iodide (PI) and $100 \mu \mathrm{g} / \mathrm{mL}$ of RNase for 45 minutes at $37^{\circ} \mathrm{C}$ in the dark. The DNA content was analyzed using a flow cytometer (Becton Dickinson, BD Biosciences, Franklin Lakes, NJ, USA). At least 10,000 cells in each sample were collected and the population of cells in each phase of the cell cycle was determined using Cell ModiFIT software (Verity Software House, Topsham, ME, USA).

\section{Assessment of intracellular ROS}

Intracellular ROS levels were monitored using $2^{\prime}, 7^{\prime}$ dichlorofluorescein diacetate. After treatment with the different concentrations of SNPs for 24 hours, the cells were harvested by centrifugation for 5 minutes at $4{ }^{\circ} \mathrm{C}$ and $1,000 \mathrm{rpm}$. Next, $2.5 \mu \mathrm{g} / \mathrm{mL} 2^{\prime}, 7^{\prime}$-dichlorofluorescein diacetate was added and staining was carried out for 20 minutes in the dark at $37^{\circ} \mathrm{C}$. The cells were then washed with phosphatebuffered saline and analyzed by flow cytometry.

\section{Assessment of mitochondrial damage}

Mitochondrial damage in the L-02 cells was estimated using MitoTracker ${ }^{\circledR}$ Green (Invitrogen, Carlsbad, CA, USA), which is a mitochondria-specific fluorescent dye. The cells were treated with different concentrations of SNPs for 24 hours. After washing with phosphate-buffered saline, the cells were stained with $50 \mu \mathrm{mol} / \mathrm{L}$ MitoTracker Green for 30 minutes in the dark at $37^{\circ} \mathrm{C}$ and then analyzed using a laser confocal microscope with Leica TCSNT software (Leica, Wetzlar, Germany).

\section{Assessment of apoptosis}

Cell apoptosis was determined using an Annexin V-FITC/PI apoptosis kit (Baosai Reagent, Baosai Biological Technology Co, Ltd, Beijing, People's Republic of China). Following treatment, the cells were harvested and resuspended in $500 \mu \mathrm{L}$ of binding buffer and $10 \mu \mathrm{L}$ of Annexin V/FITC conjugate, then incubated for 10 minutes in the dark at $4^{\circ} \mathrm{C}$. Five minutes before detection, $5 \mu \mathrm{L}$ of PI was added, and the cells were analyzed using flow cytometry at an excitation wavelength of $488 \mathrm{~nm}$ and an emission wavelength of $630 \mathrm{~nm}$. Next, 10,000 events in each sample were collected, and the apoptotic percentages were analyzed by Cell ModiFIT software. The cell nuclei were then stained with $10 \mu \mathrm{g} / \mathrm{mL}$ Hoechst 33258 solution for 45 minutes in the dark at $37^{\circ} \mathrm{C}$ and then visualized and photographed using a laser confocal microscope. Five hundred binucleated and multinucleated cells were randomly selected and the number of apoptotic cells was counted manually by two independent observers, after which the apoptotic rate in multinucleated cells was calculated.

\section{Statistical analysis}

Data for multinucleated cell numbers and rate of apoptosis in multinucleated cells were reported as frequencies and analyzed by chi-square test. Other data are expressed as the mean \pm standard deviation. Statistical analysis was performed using one-way analysis of variance with Dunnett's test. $P<0.05$ was considered to be statistically significant.

\section{Results}

\section{Characterization of SNPs}

Transmission electron microscopy showed that the amorphous SNPs were uniform in size and evenly distributed, with good monodispersity and a spherical shape (Figure 1). The average size of these nanoparticles was $53 \pm 5.1 \mathrm{~nm}$, which was determined by measuring 300 particles with ImageJ software (National Institutes of Health, Bethesda, MD, USA). The purity of the amorphous SNPs was higher 


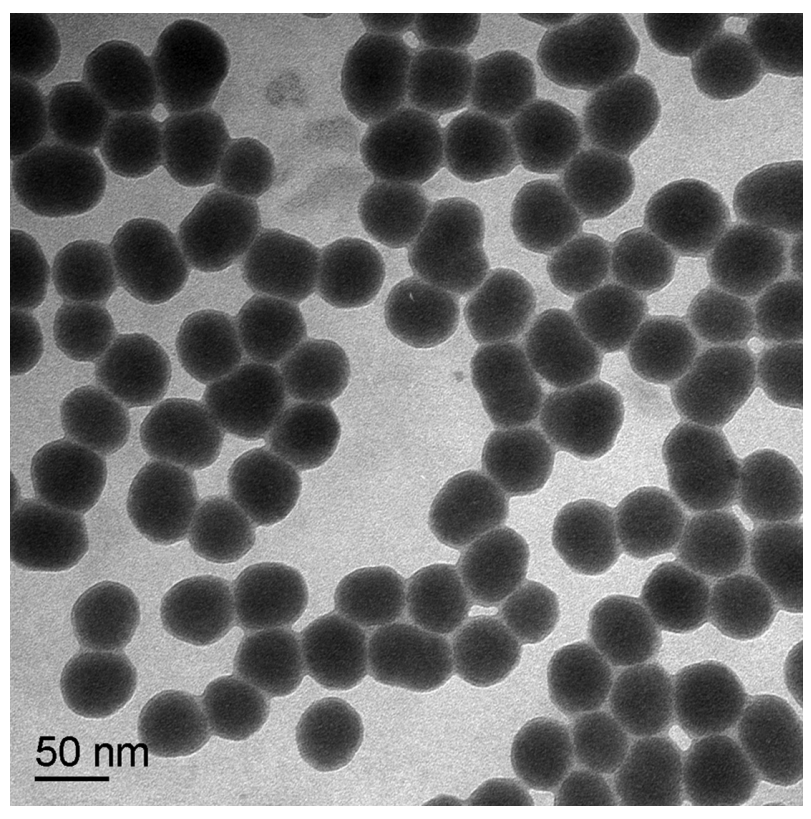

Figure I Transmission electron microscopic image of $53 \mathrm{~nm}$ amorphous silica nanoparticles.

than $99.9 \%$. Their hydrodynamic diameter and zeta potential were measured in distilled water as the stock medium and in RMPI 1640 as the exposure medium at $0,3,6$, and 24 hours to reflect their dispersion throughout the experiments. As shown in Table 1, the hydrodynamic diameter of these particles was about $90 \mathrm{~nm}$ and did not change significantly with time. Zeta potential measurement showed that the SNPs were highly negatively charged (about $-30 \mathrm{mV}$ ), indicating a fairly stable suspension in both types of dispersion medium.

\section{Cell viability}

After exposure of the cells to various concentrations of SNPs for 24 hours, cytotoxicity was estimated using a CCK-8 kit. As shown in Figure 2, the L-02 cell survival rate decreased with increasing silica exposure. Cell viability in the groups treated with $50,100,150$, and $200 \mu \mathrm{g} / \mathrm{mL}$ SNPs decreased to $71.32 \%, 54.42 \%, 40.66 \%$, and $31.89 \%$, respectively.

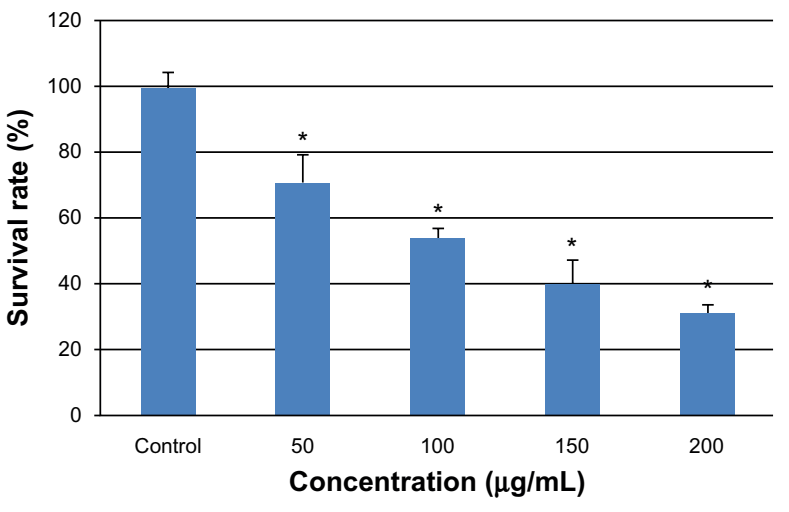

Figure 2 Viability of L-02 cells treated with different concentrations of silica nanoparticles for 24 hours. The results indicate that viability is reduced in a dosedependent manner. Data are expressed as the mean \pm standard deviation of three independent experiments. ${ }^{*} P<0.05$ versus control group using analysis of variance.

Significant differences in cell viability were seen between the group treated with $50 \mu \mathrm{g} / \mathrm{mL}$ SNPs and the control group after exposure $(P<0.05)$.

\section{Cell multinucleation}

Figure 3 shows the results of a representative multinucleation experiment in which L-02 cells were incubated with $100 \mu \mathrm{g} / \mathrm{mL}$ SNPs for 24 hours. The use of Hoechst 33258 as a DNA labeling agent enabled determination of the DNA content in all cells by measuring the integrated fluorescence emitted by each nucleus. Cells in the control group were normal with round and homogeneously stained nuclei, with only a few multinucleated cells observed, whereas giant cells containing more than one nucleus were frequently observed upon exposure to different concentrations of SNPs, suggesting that these cells had become multinucleated. Multinucleation increased in a concentration-dependent manner, increasing from $1.6 \%$ in the control group to $19.2 \%$ in the group treated with $150 \mu \mathrm{g} / \mathrm{mL}$ SNPs, and decreasing slightly to $12.6 \%$ in the group treated with $200 \mu \mathrm{g} / \mathrm{mL}$ SNPs (Table 2).

\section{Arrest of cell cycle}

To investigate the basis for multinucleation further, we examined cell cycle progression by flow cytometry. Arrest of the

Table I Time evolution of the hydrodynamic diameter and zeta potential of $53 \mathrm{~nm}$ silica nanoparticles in different dispersion medium

\begin{tabular}{|c|c|c|c|c|c|c|}
\hline \multirow{2}{*}{$\begin{array}{l}\text { Time } \\
\text { (hours) }\end{array}$} & \multicolumn{3}{|c|}{ Distilled water } & \multicolumn{3}{|c|}{ I 640 culture medium } \\
\hline & Size $(\mathrm{nm})$ & $\begin{array}{l}\text { Polydispersity } \\
\text { index }\end{array}$ & $\begin{array}{l}\text { Zeta potential } \\
(\mathrm{mV})\end{array}$ & Size $(\mathrm{nm})$ & $\begin{array}{l}\text { Polydispersity } \\
\text { index }\end{array}$ & $\begin{array}{l}\text { Zeta potential } \\
(\mathrm{mV})\end{array}$ \\
\hline 0 & 88.07 & 0.081 & -34.4 & 92.89 & 0.112 & -29.7 \\
\hline 3 & 90.25 & 0.074 & -36.1 & 89.46 & 0.089 & -31.4 \\
\hline 6 & 89.52 & 0.083 & -32.3 & 91.77 & 0.123 & -27.5 \\
\hline 24 & 87.24 & 0.067 & -35.8 & 90.02 & 0.116 & -28.8 \\
\hline
\end{tabular}



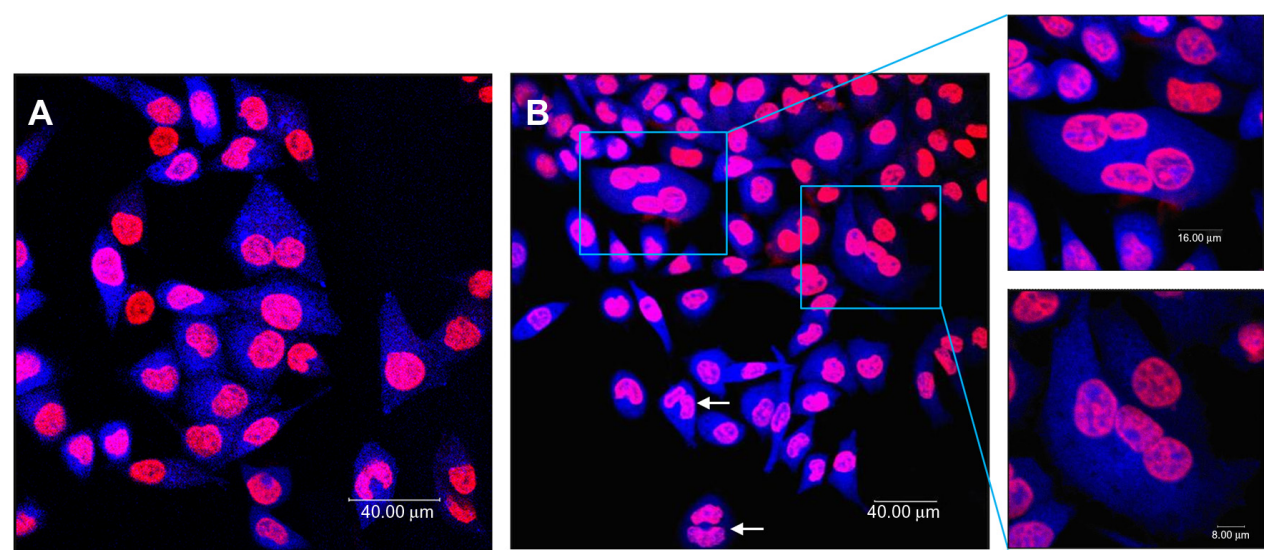

Figure 3 Multinucleation in L-02 cells induced by silica nanoparticles. (A) Control group and (B) group treated with I00 $\mu \mathrm{g} / \mathrm{mL}$ silica nanoparticles. The cell nucleus and cytoplasm were stained by Hoechst 33258 and fluorescein diacetate, respectively. Binucleated cells (arrows) and multinucleated cells (amplification) were observed.

cell cycle was observed in all four treatment groups (Figure 4). As the silica dose increased, the percentage of cells in G0/G1 phase gradually decreased, whereas the percentage of cells in $\mathrm{G} 2 / \mathrm{M}$ phase increased significantly compared with the control group $(P<0.05)$. This arrest of $\mathrm{G} 2 / \mathrm{M}$ phase corresponded to an increase in the number of multinucleated cells observed by laser confocal microscopy.

\section{Increased generation of intracellular ROS}

Intracellular ROS was determined by flow cytometry after exposing the L-02 cells to $0-200 \mu \mathrm{g} / \mathrm{mL}$ SNPs for 24 hours. The results showed a marked shift in the M2 peak of fluorescence intensity for $2^{\prime}, 7^{\prime}$-dichlorofluorescein diacetate (Figure 5A), suggesting that the SNPs caused an increase in generation of ROS in L-02 cells. The fluorescence intensity in the groups treated with $0,50,100,150$, and $200 \mu \mathrm{g} / \mathrm{mL}$

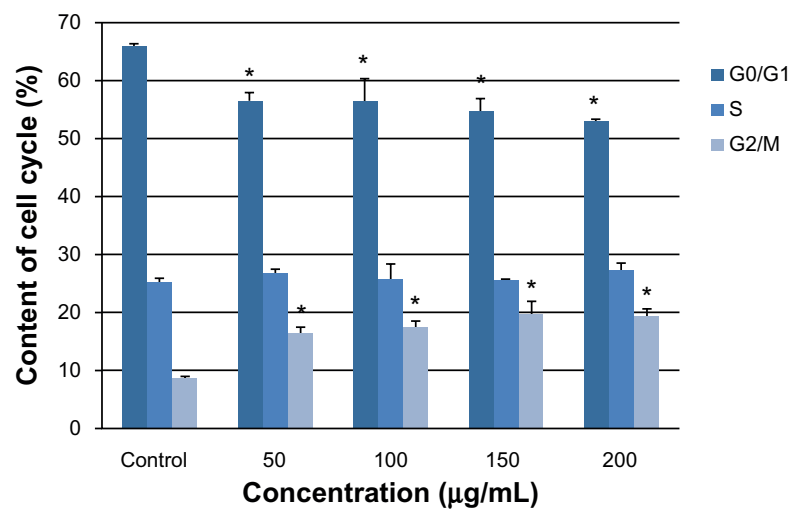

Figure $4 \mathrm{G} 2 / \mathrm{M}$ phase cell cycle arrest of L-02 cells induced by silica nanoparticles. After exposure to $50,100,150$, and $200 \mu \mathrm{g} / \mathrm{mL}$ silica nanoparticles for 24 hours, the $\mathrm{L}-02$ cell cycle was determined by flow cytometry. As the silica dose increased, the percentage of cells in G0/GI phase decreased and the percentage of cells in G2/M phase increased significantly. Data are expressed as the mean \pm standard deviation of three independent experiments. ${ }^{*} P<0.05$ versus control group using analysis of variance.
SNPs was 218.1, 385.8, 441.3, 455.4, and 588.2, respectively (Figure 5B). Concentration dependency of ROS induction was clearly observed.

\section{Mitochondrial damage}

Mitochondrial damage in L-02 cells was monitored by laser confocal microscopy using the mitochondria-specific probe,
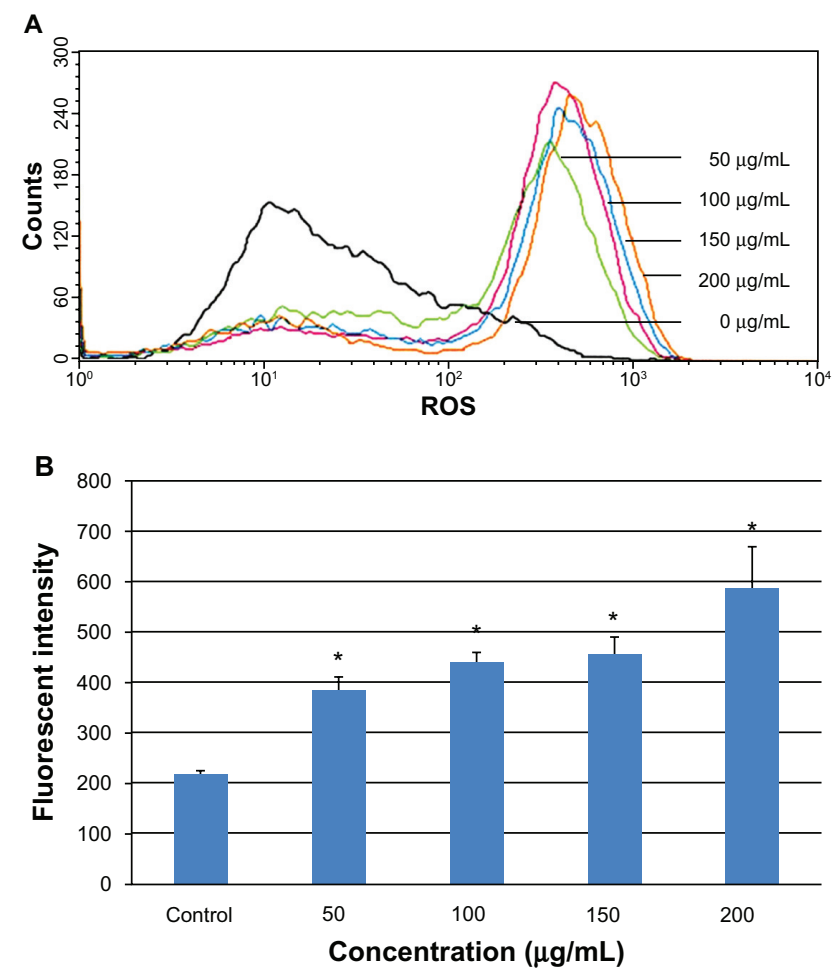

Figure $\mathbf{5}$ Change in intracellular ROS levels in L-02 cells after 24 hours of incubation with different concentrations of silica nanoparticles. The results of flow cytometry (A) and the corresponding bar graph (B) are shown. Intracellular ROS levels increased in a dose-dependent manner. Data are expressed as the mean \pm standard deviation of three independent experiments. ${ }^{*} P<0.05$ versus control group using analysis of variance.

Abbreviation: ROS, reactive oxygen species. 

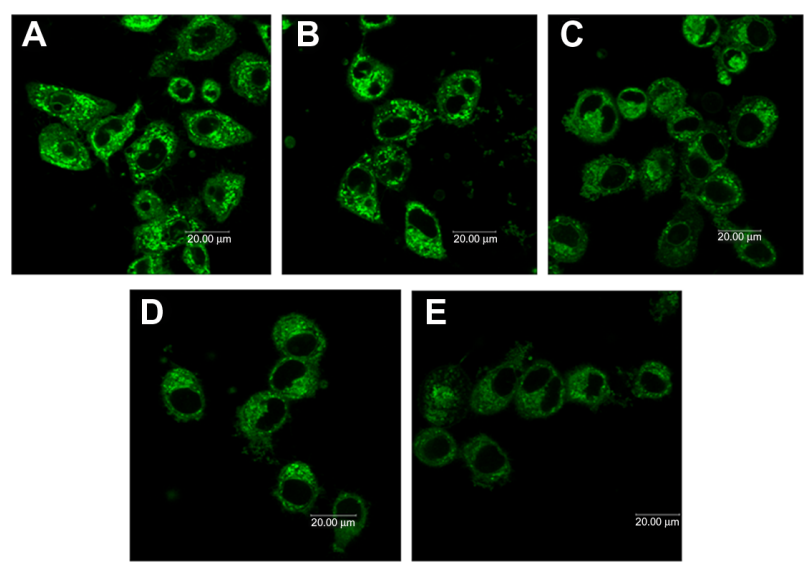

$\mathbf{F}$

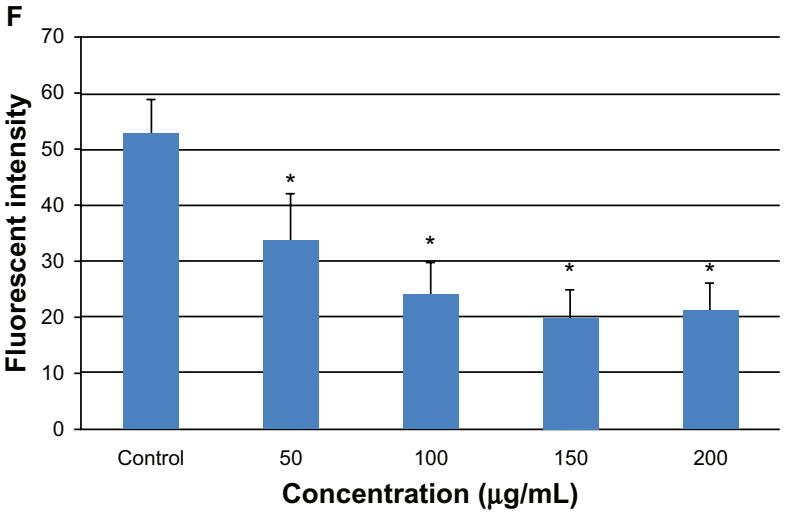

Figure 6 Mitochondrial damage to L-02 cells after exposure to different concentrations of silica nanoparticles for 24 hours detected by Mito-Tracker ${ }^{\circledR}$ green. (A) Control group, (B) group treated with $50 \mu \mathrm{g} / \mathrm{mL}$ silica nanoparticles, (C) group treated with $100 \mu \mathrm{g} / \mathrm{mL}$ silica nanoparticles, (D) group treated with $150 \mu \mathrm{g} / \mathrm{mL}$ silica nanoparticles, and (E) group treated with $200 \mu \mathrm{g} / \mathrm{mL}$ silica nanoparticles. The corresponding bar graph for flow cytometry is shown in (F). Mitochondrial damage increased in a dose-dependent manner. Data are expressed as the mean \pm standard deviation of three independent experiments. $* P<0.05$ versus control group using analysis of variance.

MitoTracker Green. Figure 6 shows that mitochondrial fluorescence intensity decreased in a dose-dependent manner on incubation of L-02 cells with SNPs for 24 hours, with increasing numbers of inactive or damaged mitochondria appearing in the group treated with SNPs.

\section{Apoptosis of $L-02$ cells}

As shown in Figure 7, the SNPs induced obvious morphologic changes in the L-02 cell nuclei. Intact and evenly stained nuclei were visualized in untreated cells, whereas condensed and aggregated chromatin was found in the groups treated with SNPs, indicating apoptotic nuclei. The apoptotic rate elevated significantly from the group treated with $50 \mu \mathrm{g} / \mathrm{mL}$ SNPs (Figure 7C). Compared with the control group, the apoptotic rate increased by $13.0 \%, 29.2 \%$, $31.3 \%$, and $33.4 \%$, respectively, after exposure to 0,50 , 100, 150 and $200 \mu \mathrm{g} / \mathrm{mL}$ SNPs for 24 hours.
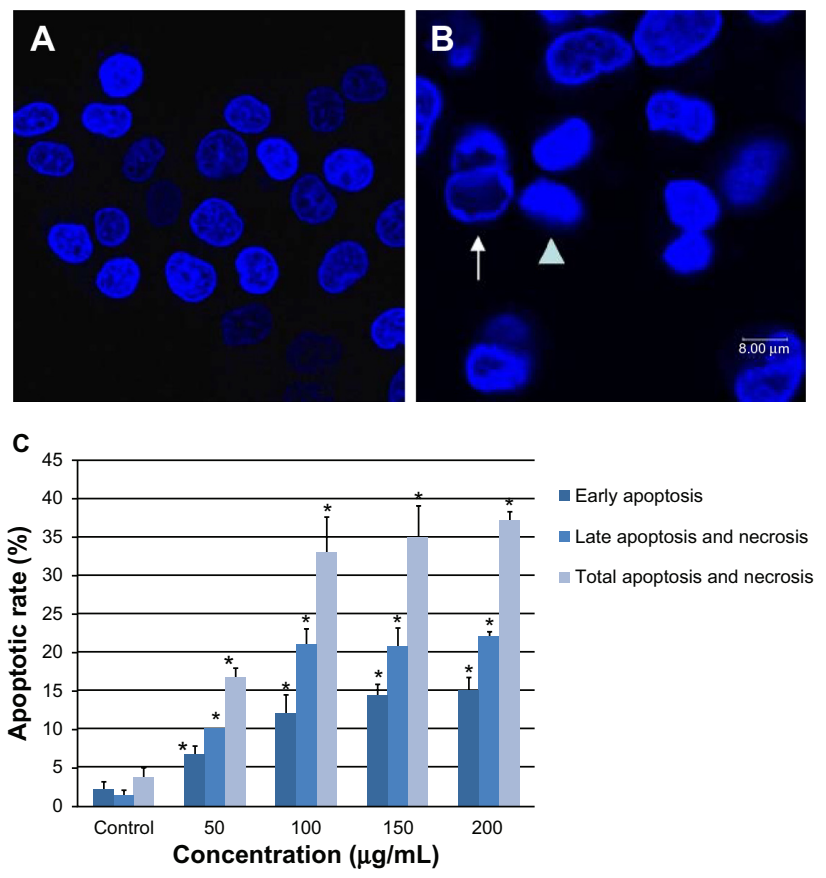

Figure 7 Apoptosis of L- 02 cells after 24 hours of incubation with silica nanoparticles. Hoechst 33258 was used to observe morphologic changes in the cell nucleus. (A) Control group and (B) group treated with $100 \mu \mathrm{g} / \mathrm{mL}$ silica nanoparticles. Nuclear condensation (arrowhead) and chromatin margination (arrow) are seen in the silica nanoparticle-treated group. The corresponding bar graph for apoptotic rate detected by flow cytometry is shown in (C). Apoptosis induced by silica nanoparticles increased in a dose-dependent manner. Data are expressed as the mean \pm standard deviation of three independent experiments. ${ }^{*} P<0.05$ versus control group using analysis of variance.

\section{Apoptosis of multinucleated cells}

We also stained the L-02 cells with Annexin V-FITC/ PI. Interestingly, some multinucleated cells could also be stained by Annexin V-FITC or PI, indicating these cells were undergoing early or late apoptosis (Figure 8). Compared with the control group, the multinuclear apoptotic rate increased significantly with increasing SNP doses (Figure 8C). In the group treated with $200 \mu \mathrm{g} / \mathrm{mL}$ SNPs, the multinuclear apoptotic rate increased to $42.85 \%$, suggesting that apoptosis was occurring in almost half of the multinuclear cells.

\section{Discussion}

In this study, we investigated multinucleation in L-02 cells after exposure to SNPs. Significant enlargement and multinucleation of L-02 cells was observed following exposure, in comparison to control cells (Figure 3). Consistent with multinucleation data, flow cytometry showed that L-02 cells treated with the different concentrations of SNPs for 24 hours exhibited a significant increase in the percentage of cells arrested in $\mathrm{G} 2 / \mathrm{M}$ phase, and in a dose-dependent manner (Figure 4). $\mathrm{G} 2 / \mathrm{M}$ arrest could be $\mathrm{G} 2$ or $\mathrm{M}$ phase arrest according to the flow cytometry analysis. However, considering multinucle- 

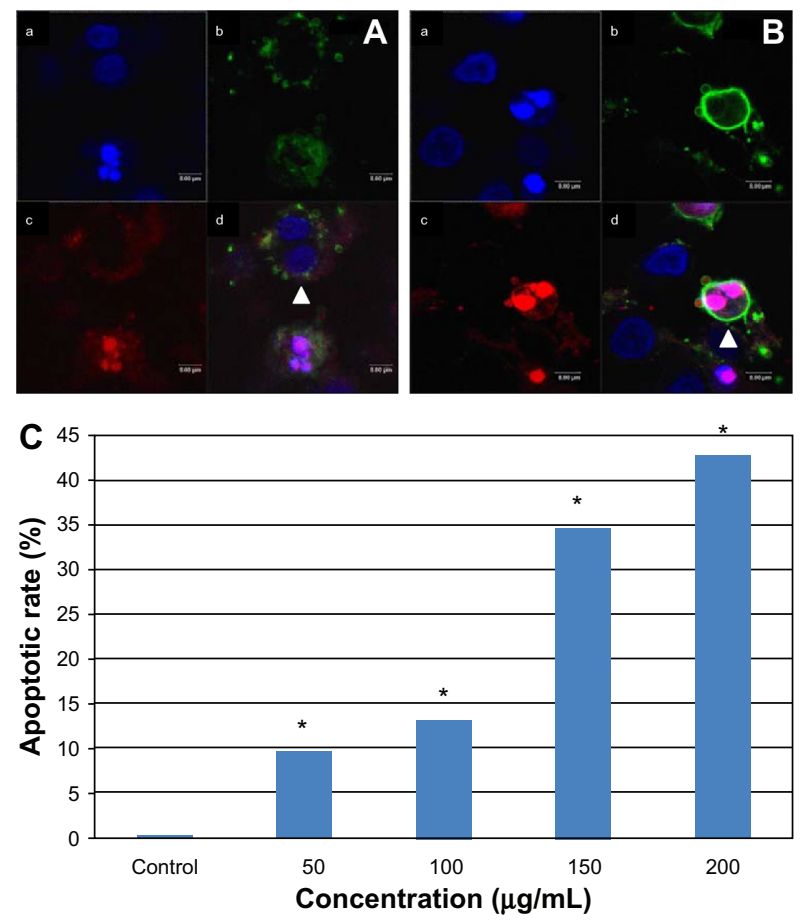

Figure 8 Apoptosis of multinucleated L-02 cells induced by silica nanoparticles. Early (A) and late (B) apoptosis of multinucleated cells was observed (arrowhead) in the group treated with $100 \mu \mathrm{g} / \mathrm{mL}$ silica nanoparticles. (a) Hoechst 33258, (b) FITCAnnexin $V(\mathbf{c})$ propidium iodide, and (d) merged image. The corresponding bar graph for apoptotic rate of multinucleated cells is shown in (C). The results indicate that the apoptotic rate of multinucleated cells also increased in a dose-dependent way. $* P<0.05$ versus control group using Chi-square test.

ation in cells, we can presume that these cells were arrested in $M$ phase with two or more separate nuclei in one single cell, rather than in G2 phase which is basically one single $4 \mathrm{n}$ nucleus in the cell. Segregation of replicated chromosomes in mitosis must be precisely coordinated with the process of cytokinesis in space and time. Failure to separate the proper complement of chromosomes into each daughter cell before cytokinesis can result in polyploidy or aneuploidy, ${ }^{32}$ which is linked to hepatocyte ploidy status during liver growth ${ }^{20}$ and development of cancer. ${ }^{21}$

Cytokinesis is the cell division process at the end of mitosis in which the membrane is physically cleaved and the daughter cells are separated after segregation of the chromosomes. Correct cytoplasmic separation involves sequential alterations in the microtubule cytoskeleton. During this process, adherent cells undergo notable changes in shape that are driven by the actin cytoskeleton and microtubule network. ${ }^{33}$ Nuclear division (karyogenesis) which is not followed by cytokinesis can lead to multinucleation. Our results show that the rate of multinucleation in L-02 cells induced by SNPs increased in a dose-dependent manner (Table 1), and the intracellular ROS level also increased as the silica dose increased (Figure 5). This suggests that the SNPs used in our study might have caused structural injury and dysfunction of microfilaments, microtubules, or centrosomes via intracellular ROS generation, leading to failure of cytokinesis and multinucleation in L-02 cells.

An insufficient supply of adenosine triphosphate (ATP) for energy during cell division might be another reason for multinucleation. Cells actively provide contractile forces for many processes, including cytokinesis and motility. Contractility is known to depend on myosin II motors which convert chemical energy from hydrolysis of ATP into forces on actin filaments. ${ }^{34}$ The mitochondria provide most of the energy required for cellular function. This energy comes from ATP, which is produced by the Krebs cycle and the electron transport chain in mitochondria through oxidation of fats, carbohydrates, and proteins. ${ }^{35}$ In our study, the number of damaged mitochondria in L-02 cells dramatically increased following treatment with SNPs for 24 hours (Figure 6), which would subsequently reduce the energy supply in the form of ATP in cells, resulting in failure of cytokinesis.

Cell fusion could also be involved in the multinucleation of L-02 cells induced by SNPs. Research has suggested that after one cell divides to generate two daughter cells, it is possible that a thin cellular bridge connecting the daughter cells still remains after cell division and the cells do not separate completely, with the daughter cells fusing to form one cell again. ${ }^{13}$ In vitro, nanoparticles can penetrate the cell membrane by diffusion or adhesion, ${ }^{36}$ and the size of these particles could be an important factor. The reaction between

Table 2 Number of binucleated and multinucleated cells induced by silica nanoparticles

\begin{tabular}{lllll}
\hline $\begin{array}{l}\text { Concentration } \\
(\mu \mathrm{g} / \mathbf{m L})\end{array}$ & Cell count & $\begin{array}{l}\text { Binucleated } \\
\text { cells }(\mathbf{n})\end{array}$ & $\begin{array}{l}\text { Multinucleated } \\
\text { cells }(\mathbf{n})\end{array}$ & $\begin{array}{l}\text { Rate of binucleated and } \\
\text { multinucleated cells }\end{array}$ \\
\hline Control & 500 & 5 & 3 & $1.6 \%$ \\
50 & 500 & 41 & 0 & $8.2 \%^{*}$ \\
100 & 500 & 69 & 3 & $14.4 \%^{*}$ \\
150 & 500 & 92 & 4 & $19.2 \%^{*}$ \\
200 & 500 & 47 & 16 & $12.6 \%^{*}$ \\
\hline
\end{tabular}

Note: $* P<0.05$ versus control group using Chi-square test. 
the particles and the cell membrane results in generation of ROS, and the oxidative stress generated might cause breakdown of the membrane lipids, ${ }^{37,38}$ which might lead to fusion of the cell membrane and result in multinucleation. Therefore, increased cellular ROS after exposure to silica could be one of the reasons for cell fusion and subsequent cell multinucleation.

In summary, multinucleation in L-02 cells is generated mainly by karyokinesis without cytokinesis and accumulation of ROS, and lack of sufficient mitochondria might contribute to this process. Cell fusion is another possible reason and should be taken into account.

Another concern is the fate of multinucleated cells. It is believed that excessive intracellular ROS levels could trigger redox signaling pathways, producing a series of cytotoxic events. ${ }^{39}$ First, high amounts of oxidative stress induced by ROS are suspected to be involved in injuring the mitochondria and perturbing the mitochondrial permeability transition pore, resulting in cellular apoptosis. ${ }^{25}$ Second, there is a clear relationship between ROS and oxidative damage to DNA. ${ }^{40}$ Therefore, increased levels of ROS in L-02 cells could also be one of the reasons for arrest of $\mathrm{G} 2 / \mathrm{M}$ phase because of the $\mathrm{G} 2 / \mathrm{M}$ check point. Cell cycle checkpoints function to ensure that cells have time to complete DNA repair, whereas apoptotic cell death may function to eliminate damaged cells that are irreparable or unrepaired. Apoptosis, a unique type of programmed cell death, plays an important role in maintenance of homeostasis and elimination of damaged cells. ${ }^{41}$ As shown in Figures 7 and 8, both mononuclear cells and multinucleated cells underwent apoptosis; in addition, the apoptosis rate increased significantly with increasing doses of silica (Figures 7C and 8C); nearly half of the cells failing to progress to mitosis are destined for apoptosis after exposure to SNPs. These findings suggest that SNPs can lead not only to multinucleation but also to apoptosis in L-02 cells.

However, the specific pathways or molecular mechanisms of multinucleation in L-02 cells induced by SNPs are far from understood. In subsequent studies, we will investigate the relationship between multinucleation and failure of cytokinesis or cell fusion further. This phenomenon and the related mechanisms need to be confirmed in animal experiments in vivo.

\section{Conclusion}

In the present study, we demonstrated that exposure to SNPs can induce multinucleation in L-02 cells in a dose-dependent manner. Our results also indicate that interaction of SNPs with L-02 cells could increase intracellular ROS levels.
Excessive ROS could induce mitochondrial or DNA damage, which would initiate the process of apoptosis in both mononuclear cells and multinucleated cells.

\section{Acknowledgments}

This work was supported by the National Natural Science Foundation of China (81172704), Innovative Team Project of Beijing Education Committee (PHR201107116), and Doctoral Program of Higher Education (20090061110062). The authors would like to thank Wensheng Yang from Jilin University for preparation of the silica nanoparticles.

\section{Disclosure}

The authors report no conflicts of interest in this work.

\section{References}

1. Oberdörster G, Oberdörster E, Oberdörster J. Nanotoxicology: an emerging discipline evolving from studies of ultrafine particles. Environ Health Perspect. 2005;113:823-839.

2. Orr G, Panther DJ, Cassens KJ, Phillips JL, Tarasevich BJ, Pounds JG. Syndecan-1 mediates the coupling of positively charged submicrometer amorphous silica particles with actin filaments across the alveolar epithelial cell membrane. Toxicol Appl Pharmacol. 2009;236:210-220.

3. Bashir MM, Navin KV, Adriele PM, et al. Activation of stress-related signalling pathway in human cells upon $\mathrm{SiO}_{2}$ nanoparticles exposure as an early indicator of cytotoxicity. J Nanobiotechnology. 2011;9:29.

4. Napierska D, Thomassen LC, Lison D, Martens JA, Hoet PH. The nanosilica hazard: another variable entity. Part Fibre Toxicol. 2010;7:39.

5. Cho WS, Choi M, Han BS, et al. Inflammatory mediators induced by intratracheal instillation of ultrafine amorphous silica particles. Toxicol Lett. 2007;175:24-33.

6. Cho M, Cho WS, Choi M, et al. The impact of size on tissue distribution and elimination by single intravenous injection of silica nanoparticles. Toxicol Lett. 2009;189:177-183.

7. Xie G, Sun J, Zhong G, Shi L, Zhang D. Biodistribution and toxicity of intravenously administered silica nanoparticles in mice. Arch Toxicol. 2010;84:183-190.

8. Mu Q, Hondow NS, Krzemiński L, Brown AP, Jeuken LJ, Routledge MN. Mechanism of cellular uptake of genotoxic silica nanoparticles. Part Fibre Toxicol. 2012;23:9-29.

9. Chen M, Mikecz A. Formation of nucleoplasmic protein aggregates impairs nuclear function in response to $\mathrm{SiO}_{2}$ nanoparticles. Exp Cell Res. 2005;305:51-62.

10. Wang JJ, Sanderson BJ, Wang H. Cytotoxicity and genotoxicity of ultrafine crystalline $\mathrm{SiO}_{2}$ particulate in cultured human lymphoblastoid cells. Environ Mol Mutagen. 2007;48:151-157.

11. Sohaebuddin SK, Thevenot PT, Baker D, Eaton JW, Tang L. Nanomaterial cytotoxicity is composition, size, and cell type dependent. Part Fibre Toxicol. 2010;7:22.

12. Rabolli V, Thomassen LC, Uwambayinema F, Martens JA, Lison D. The cytotoxic activity of amorphous silica nanoparticles is mainly influenced by surface area and not by aggregation. Toxicol Lett. 2011;206: 197-203.

13. Yoshida K, Obata S, Ono M, Esaki M, Maejima T, Sawada H. TPAinduced multinucleation of a mesenchymal stem cell-like clone is mediated primarily by karyokinesis without cytokinesis, although cell-cell fusion also occurs. Eur J Cell Biol. 2007;86:461-471.

14. Anderson JM. Multinucleated giant cells. Curr Opin Hematol. 2000;7:40-47.

15. Miyamoto T, Suda T. Differentiation and function of osteoclasts. Keio JMed. 2003;52:1-7. 
16. Junqueira LC, Carneiro J. Connective tissue. In: Basic Histology: Text and Atlas, 11th ed. New York, NY: The McGraw-Hill Companies; 2005.

17. Guidotti JE, Bregerie O, Robert A, Debey P, Brechot C, Desdouets C. Liver cell polyploidization: a pivotal role for binuclear hepatocytes. J Biol Chem. 2003;278:19095-19101.

18. Duncan AW, Hanlon Newell AE, Smith L, et al. Frequent aneuploidy among normal human hepatocytes. Gastroenterology. 2012;142: 25-28.

19. Cimini D, Fioravanti D, Tanzarella C, Degrassi F. Simultaneous inhibition of contractile ring and central spindle formation in mammalian cells treated with cytochalasin B. Chromosoma. 1998;107:479-485.

20. Ariizumi T, Ogose A, Kawashima H, Hotta T, Umezu H, Endo N. Multinucleation followed by an acytokinetic cell division in myxofibrosarcoma with giant cell proliferation. J Exp Clin Cancer Res. 2009;28:44.

21. Rao CV, Yamada HY, Yao Y, Dai W. Enhanced genomic instabilities caused by deregulated microtubule dynamics and chromosome segregation: a perspective from genetic studies in mice. Carcinogenesis. 2009;30:1469-1474.

22. Möller W, Hofer T, Ziesenis A, Karg E, Heyder J. Ultrafine particles cause cytoskeletal dysfunctions in macrophages. Toxicol Appl Pharmacol. 2002;182:197-207.

23. Jukka S, Harri A, Minnamari V, Kai S, Anne P. Proteomic characterization of engineered nanomaterial-protein interactions in relation to surface reactivity. ACS Nano. 2011;5:4300-4309.

24. Huang S, Chueh PJ, Lin YW, Shih TS, Chuang SM. Disturbed mitotic progression and genome segregation are involved in cell transformation mediated by nano-TiO 2 long-term exposure. Toxicol Appl Pharmacol. 2009;241:182-194.

25. Nel A, Xia T, Madler L, Li N. Toxic potential of materials at the nanolevel. Science. 2006;311:622-627.

26. Liu X, Sun J. Endothelial cells dysfunction induced by silica nanoparticles through oxidative stress via JNK/P53 and NF-kappaB pathways. Biomaterials. 2011;31:8198-8209.

27. Nabeshi H, Yoshikawa T, Matsuyama K, et al. Amorphous nanosilica induce endocytosis-dependent ROS generation and DNA damage in human keratinocytes. Part Fibre Toxicol. 2011;8:1.
28. Hiromi N, Tomoaki Y, Keigo M, et al. Amorphous nanosilica induce endocytosis-dependent ROS generation and DNA damage in human keratinocytes. Part Fibre Toxicol. 2011;8:1.

29. Chae S, Yun C, Um H, Lee JH, Cho H. Centrosome amplification and multinuclear phenotypes are induced by hydrogen peroxide. Exp Mol Med. 2005;37:482-487.

30. Li Y, Sun L, Jin M, et al. Size-dependent cytotoxicity of amorphous silica nanoparticles in human hepatoma HepG2 cells. Toxicol In Vitro. 2011;25:1343-1352.

31. Stöber W, Fink A, Bohn E. Controlled growth of monodisperse silica spheres in the micronsize range. J Colloid Interface Sci. 1986;26:62-69.

32. Leverson JD, Huang HK, Forsburg SL, Hunter T. The Schizosaccharomyces pombe aurora-related kinase Ark1 interacts with the inner centromere protein Pic1 and mediates chromosome segregation and cytokinesis. Mol Biol Cell. 2002;13:1132-1143.

33. Pellinen T, Tuomi S, Arjonen A, et al. Integrin trafficking regulated by Rab21 is necessary for cytokinesis. Dev Cell. 2008;15:371-385.

34. Bendix PM, Koenderink GH, Cuvelier D, et al. A quantitative analysis of contractility in active cytoskeletal protein networks. Biophys J. 2008;94:3126-3136.

35. Ricquier D, Bouillaud F. Mitochondrial uncoupling proteins: from mitochondria to the regulation of energy balance. J Physiol. 2000;529:3-10.

36. Kasper J, Hermanns MI, Bantz C, et al. Inflammatory and cytotoxic responses of an alveolar-capillary coculture model to silica nanoparticles: comparison with conventional monocultures. Part Fibre Toxicol. 2011;8:6.

37. Li SQ, Zhu RR, Zhu H, et al. Nanotoxicity of TiO(2) nanoparticles to erythrocyte in vitro. Food Chem Toxicol. 2008;46:3626-3631.

38. Choi SJ, Oh JM, Choy JH. Toxicological effects of inorganic nanoparticles on human lung cancer A549 cells. J Inorg Biochem. 2009;103:463-471.

39. Sun L, Li Y, Liu X, et al. Cytotoxicity and mitochondrial damage caused by silica nanoparticles. Toxicol In Vitro. 2011;25:1619-1629.

40. Gerloff K, Albrecht C, Boots AW, Förster I, Schins RPF. Cytotoxicity and oxidative DNA damage by nanoparticles in human intestinal Caco-2 cells. Nanotoxicology. 2009;3:355-364.

41. Doonan F, Cotter TG. Morphological assessment of apoptosis. Methods. 2008;44:200-204
International Journal of Nanomedicine

\section{Publish your work in this journal}

The International Journal of Nanomedicine is an international, peerreviewed journal focusing on the application of nanotechnology in diagnostics, therapeutics, and drug delivery systems throughout the biomedical field. This journal is indexed on PubMed Central,

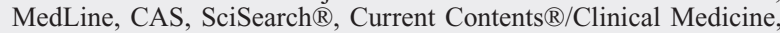

\section{Dovepress}

Journal Citation Reports/Science Edition, EMBase, Scopus and the Elsevier Bibliographic databases. The manuscript management system is completely online and includes a very quick and fair peer-review system, which is all easy to use. Visit http://www.dovepress.com/ testimonials.php to read real quotes from published authors. 